\title{
Confirmation of the northermost population of the endangered butterfly Heliconius nattereri C. Felder \& R. Felder, 1865 (Lepidoptera: Nymphalidae)
}

\author{
Márcio Zikán Cardoso ${ }^{1 *}$, Marcos Roberto Brito ${ }^{I}$ \& Marília Bruzzi Lion ${ }^{1}$ \\ ${ }^{1}$ Universidade Federal do Rio Grande do Norte, Departamento de Ecologia, 59078-900, Natal, RN, Brazil \\ *Corresponding author: Márcio Zikán Cardoso,e-mail: mzc@cb.ufrn.br
}

Cardoso, M.Z., Brito, M.R., Lion, M.B. Confirmation of the northermost population of the endangered butterfly Heliconius nattereri C. Felder \& R. Felder, 1865 (Lepidoptera: Nymphalidae). Biota Neotropica. 16(4): e20170413. http://dx.doi.org/10.1590/1676-0611-BN-2017-0413

\begin{abstract}
Heliconius nattereri C. Felder \& R. Felder, 1865 is an enigmatic and rarely collected species. Because of severe habitat reduction, the species is currently listed as endangered. We here report the confirmation of a northernmost population. This collection and further observations reported here add two more known localites to the distribution of the species. Two of the three confirmed locations are in protected areas. We worry that the northern population may be at great risk because it is not formally protected. We urge conservation efforts to preserve the local forests where the species is found.
\end{abstract}

Keywords: endangered species, conservation, Atlantic Forest, range map

\section{Confirmação de uma população no limite norte da borboleta ameaçada Heliconius nattereri C. Felder \& R. Felder, 1865 (Lepidoptera: Nymphalidae).}

\begin{abstract}
Resumo: Heliconius nattereri C. Felder \& R. Felder, 1865 é uma espécies enigmática e raramente coletada. Em função de severa perda de habitat, a espécie encontra-se atualmente listada como ameaçada. Neste trabalho, relatamos a confirmação do registro de uma população no limite norte da distribuição da espécie. Nossas coletas e outras observações aqui relatadas adicionam dois novos locais para a distribuição da espécie. Duas das três localizações confirmadas encontram-se em áreas protegidas. Nos preocupa saber que a população aqui relatada pode estar em risco por falta de proteção formal. Esforços de conservação das florestas que abrigam esta espécie são urgentemente necessários.
\end{abstract}

Palavras-chave: espécies ameaçadas, conservação, Mata Atlântica, mapa de distribuição

The species Heliconius nattereri C. Felder \& R. Felder, 1865 has inspired much interest and curiosity among butterfly enthusiasts and evolutionary biologists (Emsley 1965, Brown 1972). It is one of the rarest species in the iconic Heliconius Kluk, 1870 genus, and less than two dozen specimens had been collected until Keith Brown's rediscovery of this obscure species provided essential information regarding its basic biology (Brown 1970, 1972). It is one of the few sexually dimorphic Heliconius; females participate in the tiger mimicry ring, while the males display a yellow and black pattern (Brown 1972).

Heliconius nattereri has a very limited geographical range, from the states of Espírio Santo to Bahia, Brazil, a range that is less than $1000 \mathrm{~km}$ in length (Figure 1). Unfortunately this is also one of the most disturbed areas of the Atlantic Forest in Brazil. Populations occurs mostly on mountains above $600 \mathrm{~m}$ in Eastern Brazil, normally at low densities. Because of its limited geographical range and habitat use (dense woods), human pressure and deforestation have contributed to severe habitat loss, placing the species in the endangered category (Ministério do Meio Ambiente 2014). This means that many populations may have disappeared because of habitat reduction and deterioration caused by forest cutting, and presumably by competition from other Heliconiini that invade modified habitats (Brown 1972, Brown \& Freitas 2008). While it is encouraging to know that some populations are protected because they occur in federal reserves, such as the population in the Biological Reserve Augusto Ruschi at Santa Teresa, Espírito Santo, studied by Brown in 1972, it is nonetheless fundamental that the status of the remaining populations is assessed and the search for additional populations is needed. The National Action Plan for the Conservation of Endangered Species of Brazilian Lepidopterans (Freitas \& Marini-Filho 2011) has listed this as a critical action. To fulfill this need, our team has been carrying a long-term project with the aim of assessing current genetic diversity in remnant populations of $H$. nattereri and verifying the occurrence of the species in potential areas of its geographic range. We here report the confirmation of the occurrence of a population in the northern edge of its geographical distribution (Figure 1).

We have visited remnant forests in Amargosa, Bahia (39 $36^{\circ} \mathrm{S}, 13^{\circ} 01^{\prime} \mathrm{W}$ ) and neighboring districts, including Serra da Jibóia, in Elísio Medrado and Santa Teresinha municipalities ( $39^{\circ} 30^{\prime} \mathrm{S}, 12^{\circ} 48^{\prime} \mathrm{W}$ ), following tips from Professor Olaf Mielke (Universidade Federal do Paraná), who collected the species in Amargosa in 1997 and 2002. During a short visit in July 2013 to Amargosa municipality, we confirmed the occurrence of the host plant (Passiflora contracta Vitta, 2004), although no butterflies were seen. In April 2016, two of us (MB \& ML) spent 54 hours (six days) in the same locality and visually confirmed the presence of males and females of H. nattereri. In April 2017, we returned to the same location 


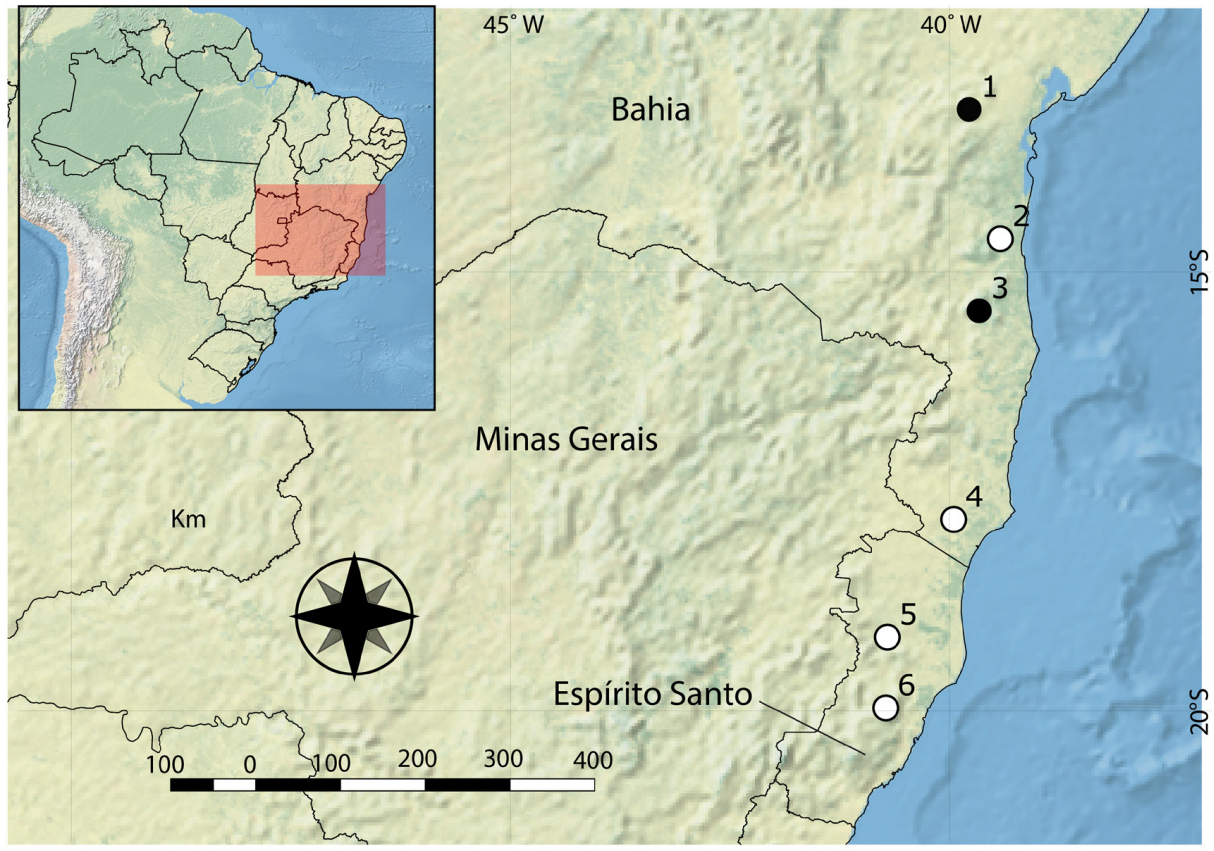

Figure 1. Heliconius nattereri range map in Eastern Brazil. Open circles are points derived from data in Brown (1979) and black circles represent our data. 1-4 Bahia 1: Amargosa, 2: Uruçuca (uncertain), 3: Camacan, 4: Posto da Mata (uncertain), 5-6 Espírito Santo. 5: Colatina (uncertain), 6: Santa Teresa.

and after five days of intensive search (7-9 hours per day) we successfully collected one male (Figure 2) while it was feeding on Gurania (Schltdl.) Cogn., 1875 flowers (Cucurbitaceae) about $10 \mathrm{~m}$ high (Figure 3). We also saw other 3 individuals flying. We thus have continued collecting evidence for the occurrence of the species in this area, this being the northernmost population reported so far. Our searches were made along trails near the entrance to the Reserva do Timbó, and consisted of systematically walking along the trails and actively searching for the butterfly. We also stopped at flower sources (Gurania) and waited for visitors to appear. There was not a systematic attempt to control for search or collection effort. We chose to collect in April as a way to avoid collecting during the colder period of June and July, when our first visit was made and very few butterflies were observed in activity.

Besides the observation of $H$. nattereri likely larval host plants (P. contracta) we also observed at least six other Passiflora species, five of which are shown in Figure 3, together with photos of the butterfly habitat. The following Heliconius were collected in the woods at or near the site of H. nattereri: H. erato (L., 1758), H. melpomene (L., 1758), H. sara (Fabricius, 1793), H. ethilla (Godart, 1819), and H. numata (Cramer, 1780). Canopy flying Philaethria Billberg, 1820 was also observed but not collected; the same with Dryas iulia (Fabricius, 1775). We did not endeavour to collected in lower lands where other species were more abundant, such as Agraulis Boisduval \& Le Conte, [1835] and some Euides Hübner, 1816. It was extremely difficult to find H. nattereri despite intensive search along trails and awaiting at feeding areas (Gurania vines), probably because of its habitat of flying high in the canopy. We could not confirm any female sightings in 2017, although some tiger pattern Heliconius were seen. Our present collection only yielded $H$. numata and H. ethilla from this color pattern.

Our finding opens the possibility of finding other undiscovered populations nearby and further to the south, although habitat destruction may make this search fruitless. We are also able to report that the butterfly was seen flying in 2016 at Serra Bonita Reserve in Camacan, Bahia, located $250 \mathrm{~km}$ away to the South, approximately midway between the Amargosa

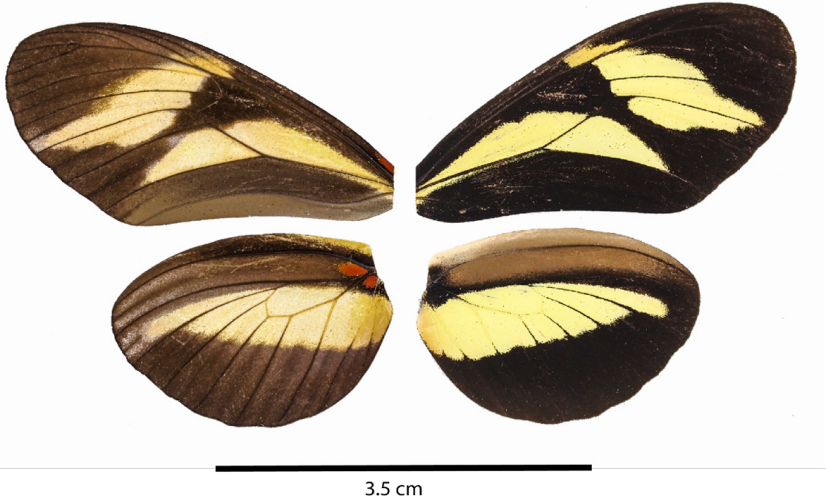

Figure 2. Heliconius nattereri (male) ventral (left) and dorsal (right) sides. Collected on 7.IV.2017, Mata do Timbó, Amargosa, BA.

and Santa Teresa populations. Sightings in Camacan have also been reported by other researchers (K. S. Brown \& A. V. L. Freitas, personal communication). Yet, a recent range map (Rosser et al. 2012) does not list these two locations, although Amargosa is shown in the Brazil's Red List Book (Machado et al. 2008). Our new range map (Figure 1) corrects these omissions, including all known localities of the species, and indicates uncertain points that have not been independently confirmed.

Given its rarity, and the seasonal occurrence and cryptic habits of the species, it will take much effort to check the existence of other remaining populations. Given the general destruction of native habitats, this could be a potentially isolated population with little or no gene flow with the other known remaining populations. Our preliminary results using whole genome sequencing of the southern population from Santa Teresa, Espírito Santo, suggests little genetic variation within the population (Massardo et al., unpublished results). The presumed lack of genetic variation should be 


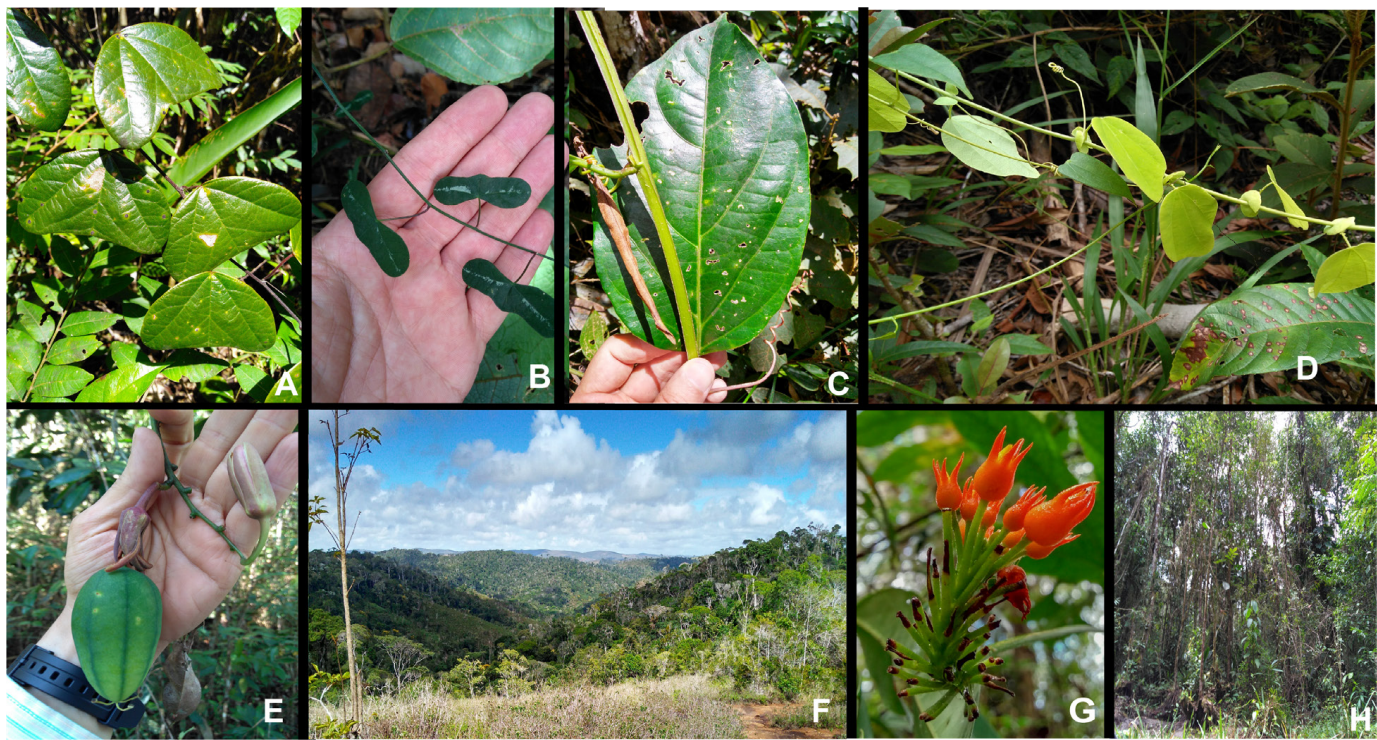

Figure 3. Habitat of Heliconius nattereri and plants in Amargosa, Bahia, Brazil. A Passiflora jiboiaensis; B P. misera; C P. alata; D P. mansoi; E P. contracta; F View of forest on mountain tops, habitat for H. nattereri. G Gurania sp pollen plant for Heliconius; H Forest clearing at forest edge in Mata do Timbó.

of great concern because the mountain range where this new population is reported is still threatened by illegal logging, even though a municipal reserve has been created in 2011 (Amargosa 2011). Early efforts in building a visitor center for the mountain range are derelict. Thus, urgent action is needed to protect these unique montane ecosystems, not only because they contain populations of the endangered Heliconius nattereri, but they are also home to other endemic butterfly species, such as the newly described Euptychia atlantica Nakahara \& Freitas, 2017 (Nakahara et al. 2017), and the endangered amphibian Proceratophrys sanctaritae Cruz \& Napoli, 2010 (Cruz \& Napoli 2010) and the aptly named Phasmahyla timbo Cruz, Napoli \& Fonseca 2008 (Cruz et al. 2008). Thus, the region not only is home to a very diverse butterfly fauna (Vasconcelos 2013, Nakahara et al. 2017), but is also a site of interest for conservation of amphibians in the Brazilian northeast (Camardelli \& Napoli 2012). We hope this report will provide support for more effective conservation actions of such important remnants. In particular, we would like to see long term mark recapture studies in the area so that the viability of this population is better assessed. Based on the repeated collections of individuals in the area, and the presence of both adult and larval hostplants, we expect that there will be a resident population there. Nevertheless, we would like to see data that not only supports this assessment, but also provides guidance for the conservation of the forest remnants.

\section{Acknowledgements}

Funds for this study have been provided by RedeLep via the SISBIOTA/Conselho Nacional de Pesquisas (CNPq) grant (Proc. 563332/2010-7) and by the Special Visiting Researcher Grant (CNPq Proc. 400242/2014-1). We would like to thank André V. L. Freitas and Olaf H. Mielke for sharing information on H. nattereri, and Onildo Marini Filho and André Freitas for critically reading this report. We also thank Jomar Jardim for identifying the Passiflora species, Marcelo Napoli for sharing information regarding amphibian biodiversity in the Amargosa region, and Kristina Schlegel for helping with graphical expertise in Figure 2. Brazil National Research Council $(\mathrm{CNPq})$ has provided additional support via a postdoctoral fellowship to MBL, a graduate fellowship to MRB, and productivity grants to MZC (Proc. 476617/2011-1; 306985/2013-6). We thank Instituto Chico Mendes de Biodiversidade for the permit to collect H. nattereri (No. 49941-1 to Márcio Z. Cardoso).

\section{Author Contributions}

M Z Cardoso: substantial contribution in the concept and design of the study, data collection, and manuscript preparation

M R Brito: substantial contribution in data collection, and manuscript preparation,

M B Lion: substantial contribution in the concept and design of the study, data collection, and manuscript preparation

\section{Conflicts of interest}

The authors declare that they have no conflicts of interest related to the publication of this manuscript.

\section{References}

AMARGOSA. 2011. Decreto no 024, de 19 de fevereiro de 2011. Cria o Refúgio de Vida Silvestre de Amargosa, no município de Amargosa, Estado da Bahia, e dá outras providências. Diário Oficial da Prefeitura Municipal de Amargosa, Amargosa, BA, Ano IV, no 278, caderno 2, 1-11.

BROWN, K.S. 1970. Rediscovery of Heliconius nattereri in eastern Brazil [The heliconians of Brazil (Lepidoptera: Nymphalidae). Part I]. Entomol. News $81: 129-140$

BROWN, K.S. 1972. The heliconians of Brazil (Lepidoptera: Nymphalidae). Part III. Ecology and biology of Heliconius nattereri, a key primitive species near extinction, and comments on the evolutionary development of Heliconius and Eueides. Zoologica 57:41-69.

BROWN, K.S. 1979. Ecologia Geográfica e Evolução nas Florestas Tropicais. Tese de Livre Docência, Universidade Estadual de Campinas, Campinas.

BROWN, K.S. \& FREITAS, A.V.L.F. 2008. Heliconius nattereri. In Livro vermelho da fauna brasileira ameaçada de extinção, vol I (A.B.M. Machado, G.M. Drummond, A.P. Paglia, eds). Ministério do Meio Ambiente e Fundação Biodiversitas, Brasília, p.414-415.

CAMARDELLI, M. \& NAPOLI, M.F. 2012. Amphibian conservation in the Caatinga biome and semiarid region of Brazil. Herpetologica 68:31-47.

CRUZ, C.A.G., NAPOLI, M.F., FONSECA, P.M. 2008. A new species of Phasmahyla Cruz, 1990 (Anura: Hylidae) from the state of Bahia, Brazil. S. Am. J. Herpetol. 3:187-195. 
CRUZ, C.A.G. \& NAPOLI, M.F. 2010. A new species of smooth horned frog, genus Proceratophrys Miranda-Ribeiro (Amphibia: Anura: Cycloramphidae), from the Atlantic Rainforest of eastern Bahia, Brazil. Zootaxa 2660:57-67.

EMSLEY, M.G. 1965. Speciation in Heliconius (Lep.: Nymphalidae): morphology and geographic distribution. Zoologica 50:191-254.

FREITAS, A.V.L., MARINI-FILHO, O.J. (eds). 2011. Plano de Ação Nacional para Conservação dos Lepidópteros Ameaçados de Extinção. Instituto Chico Mendes de Conservação da Biodiversidade, Brasília.

MACHADO, A.B.M., DRUMMOND, G.M., PAGLIA, A.P. (eds). 2008. Livro vermelho da fauna brasileira ameaçada de extinção, vol I. Ministério do Meio Ambiente e Fundação Biodiversitas, Brasília.

MINISTÉRIO DO MEIO AMBIENTE. 2014. Lista Nacional das Espécies Ameaçadas de Extinção. Diário Oficial da União, Seção I, 245:121-144.
NAKAHARA, S., BARBOSA, E.P., FREITAS, A.V.L. 2017. A potentially endangered new species of Euptychia Hübner, 1818 (Lepidoptera: Nymphalidae: Satyrinae) from the Atlantic coastal forest of Brazil. Neotrop. Entomol. 46:302-309.

ROSSER, N.R., PHILLIMORE, A.B., HUERTAS, B., WILLMOTT, K.R., MALLET, J. 2012. Testing historical explanations for gradients in species richness in heliconiine butterflies of tropical America. Biol. J. Linn. Soc. 105:479-497.

VASCONCELOS, R.N. 2013. Refúgios biogeográficos, estrutura da paisagem e limiares extinção associados a perda de habitat. Tese de Doutorado, Universidade Federal da Bahia, Bahia.

Received: 28/07/2017

Revised: $31 / 10 / 2017$

Accepted: 03/11/2017

Published online: 27/11/2017 